\section{Ippolito Donini}

\section{Vincenzo Gasbarro}

Vascular Surgery, University of Ferrara; and Operative Unit of Vascular Surgery, University Hospital S. Anna, Ferrara, Italy

\section{... authoritative but never authoritarian Master}

Born in the countryside around the city of Cremona, in northern Italy, precisely in the village of Pizzighettone, on April $7^{\text {th }}$, 1929, Ippolito Donini obtained his degree in Medicine and Surgery from the University of Parma. Then he enrolled in the School of Anatomy directed by Professor Ottaviani, the most renowned expert in the study of the anatomy of the lymphatic system in Italy. He rapidly passed from the dissection table to the operating table and then entered the surgical school of Professor Battezzati, whom he followed when he was called to direct the Institute of Surgical Pathology in Genoa. Here Professor Donini continued to deal with lymphatic surgery and, with the young Fabrizio Bresadola, developed a method of lymphatic-venous anastomosis using a patch that is still considered to be an absolutely innovative technique for that time. In those years the editor Piccin published The lymphatic system in clinical practice $^{1}$ (Figure 1), still a basic text today for the study of the pathophysiology and treatment of lymphedema. After teaching surgical semeiotics at the University of Sassari, in November 1971 he was called to direct the Surgical Department of the University of Ferrara, where he started the most important period of his career as a surgeon and teacher for all of us. The Institute filled up with young aspiring surgeons attracted by the enthusiasm of this young surgeon who came from Genoa (he was only 41 years old at the time!).

In the following years, his talent as a clinician and surgeon reached full maturation, above all at the operating table, where he successfully resolved extremely difficult situations with unparalleled naturalness and simplicity.

Many excellent surgeons were trained in Ferrara in the 80's and 90's and then obtained surgical chairs in prestigious universities such as Bari, Sassari, Udine, Ancona, Ferrara, and Perugia, which actually confirmed the role of Master of Prof. Donini and recognized for all of us the honor of being part of a great School of Surgery.
Beyond surgery, he never abandoned his passion for vascular diseases and pushed many of us to continue the studies he had undertaken in his youth.

With his charisma, in 1986 he managed to gather first level clinical and professional experiences and gave birth to the Italian Society of Phlebolymphology, which still today represents a reference society in this field.

Deeply convinced that these two vascular systems were a single morpho-functional entity with relationships still completely unexplored, he wanted to highlight his point of view, collecting them in a single term, Phlebolymphology, entrusting to the mission of the newly born society the task of following, more than any other, the cultural address he traced.

In his pursuit of the unification of the various souls of Italian phlebology within a single scientific society, in the 1990s he personally committed to working on that project and, after long and exhausting negotiations, finally, in July 1996, the Italian College of Phlebology was founded in Rome and with him as Honorary President.

In 1999, together with other distinguished representatives of Italian universities, he promoted the birth of the Interuniversity Center of Phlebology, where research doctorates in phlebology would be held in the following years - a unique academic experience in Italy. His academic activity in those years had its apex in the appointment as Rector of the young University of San Marino, so it was precisely in the Republic of Mount Titano that the teaching of phlebolymphology acquired new impetus with the organization of Master Degree courses with the best Italian experts as teachers.

In October 2000, the $4^{\text {th }}$ Congress of the Italian College of Phlebology was held in Ferrara, chaired by him, as a great tribute and recognition by the entire national and international scientific community.

In the following years, even after leaving the scalpel in 2004, he kept spurring everybody on to continue his teaching in modern phlebology based on practicality and care for the patient as essential values.

With him at our side, we have never been left without support, as he constantly offered his experience and balance. So, it was with this motivation that, when it was time to organize the $15^{\text {th }}$ Congress of the Italian College of Phlebology, in October 2011, I drew from his teachings with full hands to organize an event that, as everybody said, was to mark one of the highest moments of Italian phlebology. On that occasion I had the privilege of having him at my side in the opening ceremony of the
Correspondence: Vincenzo Gasbarro, Vascular Surgery, University of Ferrara; and Operative Unit of Vascular Surgery, University Hospital S. Anna, Ferrara, Italy. E-mail: gsv@unife.it

Key words: Italian Phlebolymphology; history; Masters of the past; phlebology; lymphology.

Conflict of interests: the author declares no potential conflict of interests.

This paper is part of the monographic issue: 'Did the Masters of the past know the future? History and update of Italian Phlebolymphology' - Guest editor: Alberto Macciò (Phlebology - Part I edited by G. Agus; Phlebology - Part II edited by P. Bonadeo; Lymphology edited by F. Boccardo).

Received for publication: 30 June 2020.

Revision received: 10 July 2020 .

Accepted for publication: 15 July 2020.

This work is licensed under a Creative Commons Attribution 4.0 License (by-nc 4.0).

${ }^{\circ}$ Copyright: the Author(s), 2020

Licensee PAGEPress, Italy

Veins and Lymphatics 2020; 9:9248

doi:10.4081/vl.2020.9248

congress dedicated to him: unrepeatable moments of great significance for me.

In these last few lines I would like to remember Ippolito Donini as a man and as a father for many of us. The first of many

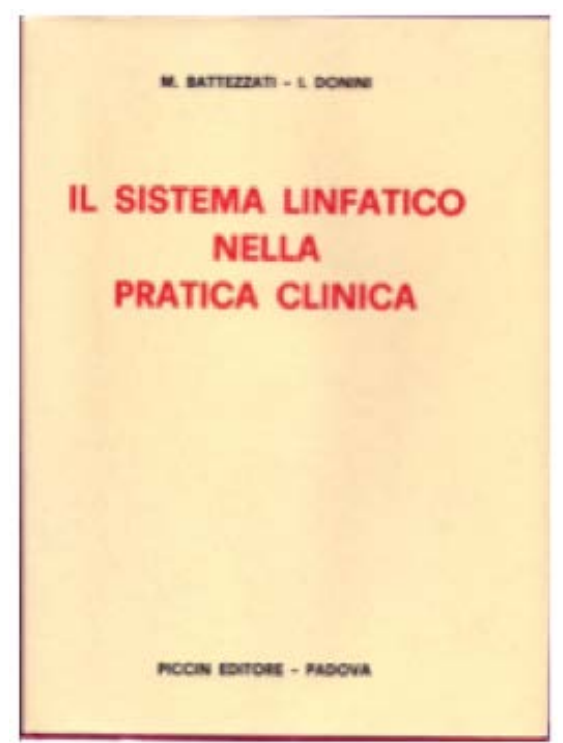

Figure 1. First edition of The lymphatic system in clinical practice, 1967. 
memories I have is the way he used to speak with us: he was always nice and warm, never aloof; he could immediately establish a feeling of harmony with people, almost of closeness with the persons he met. This was due to his politeness, his ability to be immediately on familiar speaking terms with everybody, thus making his interlocutors feel at ease, so much so that one immediately opened up his or her heart to him, almost by magic.

Another intense memory is that of his charisma, which he often denied, the way how he talked to patients and how these, after a few words from him (he was not very talkative), felt like energized... We all wondered where all this came from, in him. Only now, after a long time spent with him, I can say that it was all in his gestures, he always gently touched them, and this permitted the transfer, an almost mystical transfer of his positive energy. The patients loved him.

I hope that this brief writing of mine has been effective in fully explaining the force of the memory I wanted to convey of a Master who will always remain in our gestures and in our hearts.

\section{References}

1. Battezzati M, Donini L. Il Sistema linfatico nella pratica clinica. Padova: Piccin Editore; 1967. 